\title{
Payments for environmental services and community-level socioeconomic wellbeing: Comparing programs in Vietnam and Australia
}

\author{
MIA SANDGREN
}

\section{Abstract}

The success of Payments for Environmental Services (PES) programs depend crucially on local conditions, although some considerations can help make PES schemes more successful in any locale. Many PES programs are in their infancy yet have ambitious goals for environmental preservation and poverty alleviation. Monitoring and evaluating the outcomes of PES programs can provide insights into how they can best achieve these goals. This research adds to existing PES case studies by evaluating new data on one village's participation in a World Wildlife Fund PES scheme. A village in central Vietnam was visited and the Administrative Chief of the village was interviewed to gauge the success of the PES scheme in that village. The comments from the Vietnamese village were then compared to written and verbal accounts of the Working on Country program in Australia to elucidate factors that can make PES schemes successful. This comparison revealed four key factors that can improve the outcomes of PES schemes. Community involvement in the design, implementation and evaluation of projects is crucial. Furthermore, the monetary remuneration that the community receives should be adequate. In addition, PES schemes are particularly successful when the community receives non-monetary benefits, such as social or cultural benefits, from participating in the program. Finally, the involvement of outside organisations, including the state, needs to be adequate and appropriate to ensure positive socioeconomic outcomes for the communities involved. 


\section{Introduction}

The Millennium Ecosystem Assessment cemented in the international consciousness the notion that there are three important aspects of sustainabilityeconomic development, environmental health and social development-that cannot be pursued in isolation (Millennium Ecosystem Assessment 2005). However, finding policies that support all three aspects of sustainability has proven difficult. Payments for Environmental Services (PES) represent one attempt to integrate environmental and socioeconomic goals.

This report will present a comparative analysis of two PES programs to answer the question: how can payments for environmental services contribute to the socioeconomic wellbeing of communities? Four key factors that allow PES programs to deliver socioeconomic benefits will be discussed: community involvement, adequate monetary remuneration, community improvement and the appropriate participation of outside organisations. Results gathered in an ethnic-minority village visited during a university field school in Vietnam (see Appendix 1) will highlight some pitfalls that impinge on the success of PES. An Australian example involving Indigenous Australians will provide insights into how PES can successfully deliver socioeconomic outcomes.

\section{Background}

\section{Payments for environmental services}

Two key observations led to a global rise in community-based natural resource management and, subsequently, PES (Tsing et al.2005; Menon et al.2007). Firstly, it was acknowledged that communities that live near areas of environmental significance could positively contribute to the management and protection of those areas (Colfer 2005; Tole 2010; May 2010). Secondly, environmental management was recognised as a potential vehicle for poverty alleviation because the poorest people are often the most directly dependent on and connected with their environment (Asia News Monitor 2009; Boissière et al. 2009; Adhikari \& Agrawal 2013; WWF 2015). Hence, researchers, non-government organisations (NGOs) and governments have been exploring how PES can help support livelihoods.

Broadly understood, PES make preserving environmentally valuable land more profitable for those managing the land (The \& Ngoc 2008). 'Sellers' protect and manage environments that provide environmental services, such as watershed protection, biodiversity preservation, landscape beauty or carbon sequestration (Thuy et al. 2013). 'Buyers' who benefit from environmental services provide remuneration to the sellers. By definition, PES is a mechanism for achieving environmental outcomes only. Any poverty-related improvements are "beneficial 
side-effects' (Wunder 2013: 231). Yet socioeconomic improvements are often discussed in association with PES (Pagiola et al. 2005; McElwee 2012; Thuy et al. 2013; Adhikari \& Agrawal 2013; Mansourian \& Vallauri 2014).

In practice, neither environmental nor wellbeing benefits have been widely achieved by PES. Adhikari and Agrawal's (2013) review of 27 PES programs globally found mostly limited livelihood improvements and highly varied environmental outcomes. To et al. (2012: 248) concluded that 'there has been no clear evidence that PES [in Vietnam] will be an effective mechanism for ... improving the livelihoods of the rural poor ... [or] improving forest quality'. Yet, there are successful examples and models, as this report will illustrate.

Monitoring and evaluating individual case projects is important (Colfer 2005; Tole 2010). Local conditions influence the success or otherwise of PES programs, as strategies that work in one context may not work in another (Tole 2010). Yet there are certain actions that, regardless of an environmental program's location, might increase the likelihood of its success (Measham \& Lumbasi 2013). Identifying what causes programs to fail or to succeed can help improve future programs.

\section{Forests and forest management in Vietnam}

Forests account for 40 per cent of Vietnam's land area (The \& Ngoc 2008). Most of the country's forests are natural forests, although there are substantial areas of plantations (Sam \& Trung 2001). These natural forests are of environmental, social, cultural and economic importance.

Forests are cut down for utilitarian reasons such as production and land use conversion. Wood is widely used for fuel, furniture production and construction. Industrially, Vietnam has a burgeoning woodchip and paper industry that relies on plantations (Hidayat et al. 2012). Swidden agriculture remains the basis of some communities' livelihoods, although it is now prohibited (Bayrak et al. 2013). Natural forests are threatened by population growth (Vu et al. 2014), illegal logging (McElwee 2009) and the economic advantages of using land for agriculture (To et al. 2012; Dressler et al. 2013) or plantations (Sodhi et al. 2010).

On the other hand, forests are left standing to preserve the environmental services they provide and for social reasons. Mature forests are particularly important for biodiversity because they are generally more species rich, abundant and diverse than plantations (Sodhi et al. 2010). Forests protect soil and water quality, which supports Vietnam's agricultural production. The carbon sequestration potential of forests is also valued. In addition, non-timber forest products are collected from forests and forests attract visitors from all over the world. Some Vietnamese 
consider forests to be spiritual entities; forests are often incorporated into cultural practices and some communities' institutions and social structures are forest-based (Bayrak et al. 2013).

In response to these competing values, Vietnamese forest management has changed considerably in the past few decades. A period of deforestation between 1943 and 1991 saw forest cover reduced from 43 to 29 per cent (The \& Ngoc 2008). A substantial and successful reforestation program was then implemented, based around the decentralisation of forest management (McElwee 2009; Pham et al. 2010; Thuy et al. 2013). The use rights of forests were transferred from the state to those living near forests. In line with international thinking, it was reasoned that local communities and individuals would have the incentive to use and manage forests more appropriately than the state (Sam \& Trung 2001). Today, Vietnamese forest policy is fundamentally aimed at both increasing environmental health and poverty alleviation (Sam \& Trung 2001; Asia News Monitor 2009). This recognises that poor people in Vietnam are more likely to live near forests, be dependent on them, be affected by their degradation and benefit from their proper management (The \& Ngoc 2008; Barbier 2010). As a result, there are now a number of PES programs operating in Vietnam, such as the one in the study village (Thuy et al. 2013; McElwee 2012).

\section{Indigenous Australians and environmental management}

Like Vietnam, Australia has large areas of environmental significance, although not all are classified as forests. Natural vegetation communities, including forests, grasslands and savannahs, ensure environmental health, support endemic species, are aesthetically valuable and provide opportunities for recreation. Over the last two centuries, clearing for pastures, agriculture and urban development, as well as a lack of appropriate management, has caused continent-wide land degradation.

Australian Indigenous peoples hold special connections to the land; their culture, customs, law and health are intimately related to Country. Indigenous people's traditional knowledge of Country is increasingly being recognised as holding unique potential for improving the management of the environment (Baker et al. 2001; May 2010), particularly because of the high proportion of environmentally significant areas that are Indigenous-owned and the number of Indigenous people who reside in these otherwise remote areas (Altman 2012). The establishment of Indigenous Protected Areas, joint-management initiatives, Caring for Our Country and Working on Country (WoC) reflect this growing awareness (Baker et al. 2001). 
WoC is an Australian Government-funded program employing Indigenous rangers to undertake natural resource management activities such as fire abatement, feral animal and weed control and maintaining ecologically significant systems (Ryan 2012; Warddeken Land Management Limited 2012). The program is not explicitly and solely a PES program. However, it is based around the same idea: providing financial remuneration for managing landscapes and preserving the services they provide.It is a reflection of 'the potential to address Indigenous poverty and [natural resource management] simultaneously' (May 2010: 408). Despite having to work through many barriers and challenges, $\mathrm{WoC}$ has had positive environmental, social and economic outcomes for communities.

\section{Methods}

A visit to the study village was organised. Visual observations were collected. Conversations with villagers and a semi-structured interview with a village official were conducted, facilitated by a translator. The results from these experiences were used to guide a literature review of peer-reviewed journals, government documents, official reports, news sources and print materials about the history of forest management in Vietnam, community-based management and PES (see Appendix 1).

A review of the WoC program was undertaken. Written reviews of the program by both European and Indigenous authors were consulted. An academic who has worked with communities participating in the WoC program was consulted.

\section{The study village}

The study village was located in the remote central highlands of Vietnam. Approximately 340 people lived in the village. The villagers were Co Tu people, an ethnic minority in Vietnam who have their own culture and speak their own language (Bayrak et al. 2013). Most villagers were subsistence farmers, cultivating rice and cassava, tending cassia and acacia forests and raising animals for ceremonies and consumption. Old-growth forests surrounded the village (Figure 1). The village also had an agreement with a tourist company that maintained accommodation for tourists. Villagers were paid to provide services for tourists, including preparing meals, performing ceremonies, selling handicrafts, running homestays and guiding hikes. 


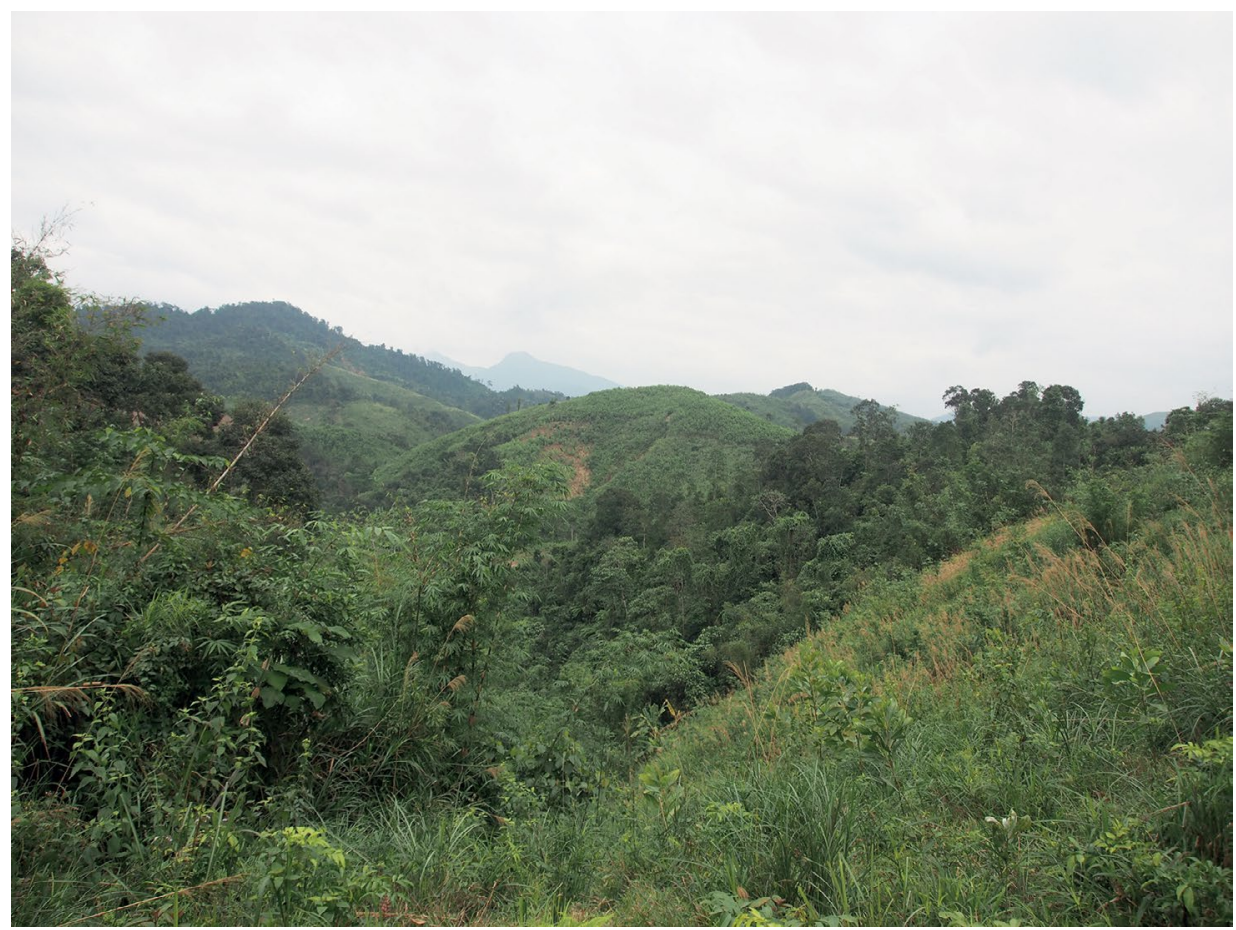

Figure 1: Forests near the study village. Note both plantation (centre, middle ground) and natural (centre-left, background) forests.

Photograph: Author, 2015.

\section{Results}

\section{In-country findings}

The Administrative Chief (AC) of the study village was administering a community-based forest management program sponsored by the World Wildlife Fund (WWF) and the German Development Bank. The AC knew that this program involved four other provinces in Vietnam and understood the aim of the program to be the restoration of 100,000 hectares of forest. The project had been active in his village for two years.

The AC was in charge of managing the villagers and distributing the money. A number of groups in the village, each with their own leader, were periodically sent to patrol the old-growth forests surrounding the village. The AC explicitly identified the key benefits and limitations of the program. His comments are summarised in Table 1. 
Table 1: Benefits and limitations of the forest management program according to the Administrative Chief of the study village.

\begin{tabular}{|c|c|}
\hline Benefits & Limitations \\
\hline $\begin{array}{l}\text { - Visible improvement in biodiversity, } \\
\text { - Imch as more wild animals } \\
\text { - } \quad \text { Financial benentits received by villagers } \\
\text { for their work } \\
\text { - Improved environmental awareness } \\
\text { in the village } \\
\text { - Illegal hunters and loggers had been } \\
\text { kept out of the forest }\end{array}$ & $\begin{array}{l}\text { - Villagers could no longer harvest food } \\
\text { and forest products from the forests } \\
\text { - Payment is inadequate } \\
\text { - The agreement could not be changed } \\
\text { - Payments would not increase }\end{array}$ \\
\hline
\end{tabular}

Source: Author's fieldwork.

The $\mathrm{AC}$ reported that the village was receiving 58 million Vietnamese dong (approximately AU\$3,500) every three months. This was distributed equally between the 340 villagers, as per a consensus agreement in the village. The AC suggested that the remuneration they received was one-tenth of the benefit they would gain from collecting products in the forest.

The AC stated that the program was a 'process from above'. He stated that there was no chance that they would be released from the program and the payments would not be increased. He said that people were adapting to not being able to harvest forest products by putting more effort into agriculture, although villagers did collect forest products while they patrolled the forest. It was implied that the limitations of the program outweighed the environmental and direct economic benefits outlined in Table 1 .

\section{Data collection issues}

The short time period available for fieldwork in the study village, the limited opportunities to discuss the program with multiple stakeholders and the use of translators puts limitations on the data collected. No data was collected from those who performed the forest management and it was not possible to corroborate the AC's perception of the program's benefits and limitations with empirical evidence in the village. It is possible that the tone of the conversation was also misinterpreted. However, the results still provide first-hand insights from a highly involved and oft-marginalised stakeholder (Pham et al. 2010), from which some interesting comparisons and conclusions can be drawn.

\section{Discussion}

The study village is just one example in a class of environmental services payment programs run by governments (Thuy et al. 2013), NGOs (Pham et al. 2010) and independent buyers (To et al. 2012; McElwee 2012), both in Vietnam and globally 
(The \& Ngoc 2008; Adhikari \& Agrawal 2013). This program was part of the WWF's project: Avoidance of deforestation and forest degradation in the border area of Southern Laos and central Vietnam for the long-term preservation of carbon sinks and biodiversity 'CarBi Project' (Figure 2) (WWF 2015). This project aims to support the socioeconomic development of those involved in achieving the environmental goals of the project stated in its title (WWF 2015). The WWF is reporting positive outcomes such as the creation of employment hours and capacity building for the communities involved (Bekker 2015). However, the findings from the study village suggest that the quantifying measures used by the WWF to assess outcomes do not fully reflect the local impacts of the project. Thus, detailed local reviews of the socioeconomic outcomes of PES programs are important.

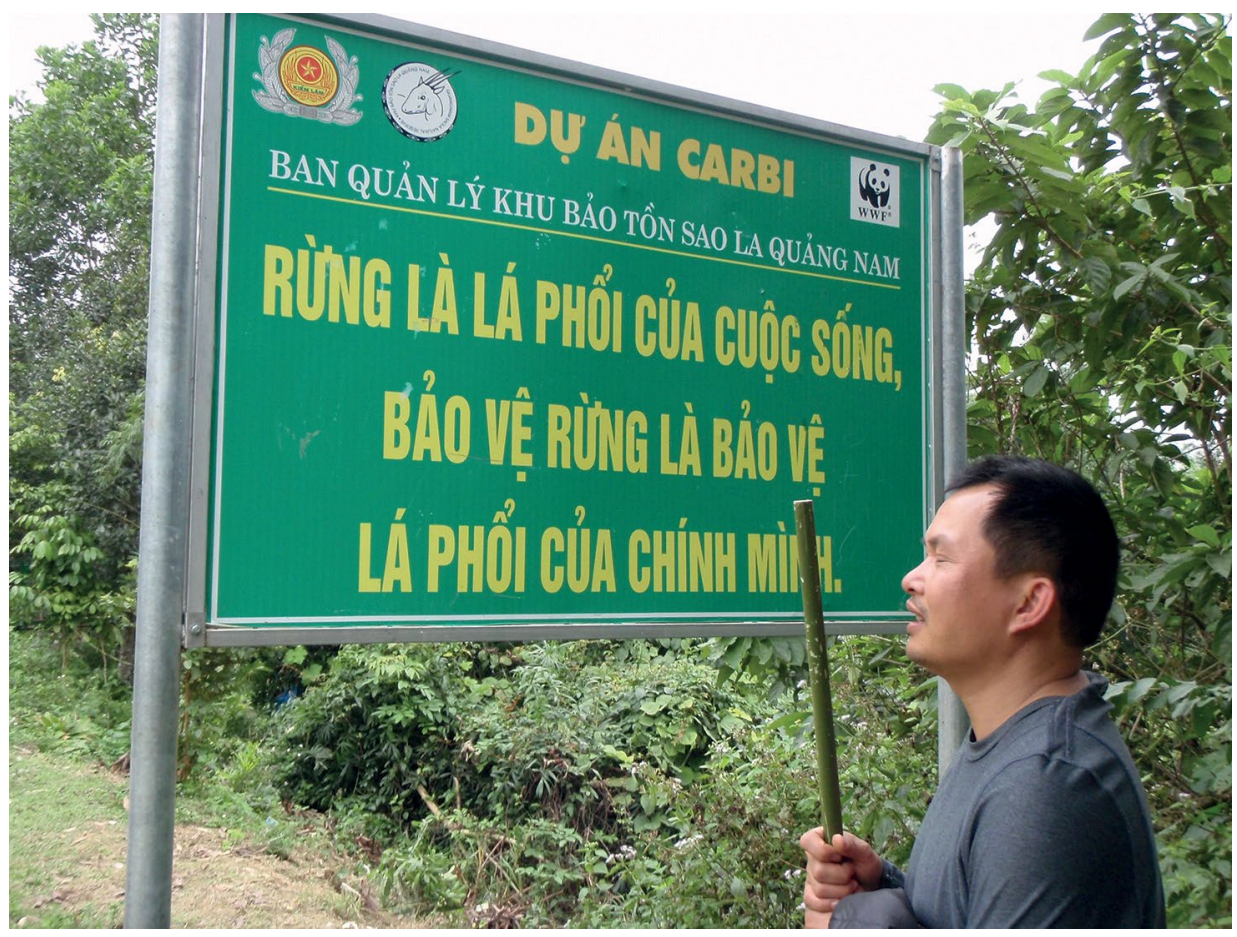

Figure 2: Sign advertising the CarBi Project in the study village. Note the World Wildlife Fund logo and a quotation from Ho Chi Minh: 'Forests are the lungs of life, protect[ing] the forests is protecting our own lungs.' Translated by Trung Dang Dinh. Photograph: David Freudenberger, 2015.

By comparing processes and outcomes in the study village (the Results) with the WoC program in Australia, this report will demonstrate how four factors help PES schemes deliver wellbeing benefits to communities. As stated earlier, these are community involvement, adequate monetary remuneration, community improvement and the appropriate participation of outside organisations. 


\section{Community involvement in planning, implementing and evaluating programs}

It appeared that in the study village, the community did not design the PES scheme and had not been involved in reviewing it. This lack of involvement caused the community's needs and preferences to be overshadowed by wider conservation goals. The result was dissatisfaction and adverse outcomes.

WoC, on the other hand, is a state-sponsored program that evolved from existing, community-instigated programs (May 2010; Green \& Morrison 2012). The programs reflect community interest in environmental preservation and local concerns (Marika et al. 2012). Communities have been consulted at all stages of the projects to ensure their needs are taken into account (Ryan 2012). This is considered fundamental to the program's success (Ryan 2012; Marika et al. 2012).

Many reviews of community environmental management and PES advocate for strong community involvement and claim that community involvement is a crucial feature of successful programs (Baker et al. 2001; Colfer 2005; Sheil et al. 2006; Boissière et al. 2009; Mustalahti 2009; May 2010; Tole 2010; Altman 2012; Thuy et al. 2013; KimDung, et al. 2013; Measham \& Lumbasi 2013). This suggests that PES are more successful when communities are consulted about the nature and extent of their involvement and provide the impetus for the program. That is, programs work best when sellers of environmental services seek out buyerssuch as communities seeking out governments—rather than the other way around. Community support ensures commitment to the environmental goals of the program and, in turn, the program's longevity. When this is achieved, programs will have a greater capacity to benefit communities socioeconomically.

\section{Communities receiving adequate monetary remuneration or incentives for environmental protection}

In the study village, the payments for protecting the forest did not adequately compensate for lost harvests of timber and non-timber forest products. Bayrak et al. (2013) found that Co Tu people are highly forest-dependent and have a culture of sustainably harvesting forest products. Through the CarBi Project, the WWF is attempting to provide 'alternative livelihoods' for communities who are otherwise dependent on forest product harvesting (WWF 2015). Reportedly, the project also allows communities to use forest resources sustainably (WWF 2015) and the WWF acknowledges the importance of incorporating this allowance into the design of successful environmental restoration projects (Mansourian \& Vallauri 2014). However, the results suggest that the program does not provide an adequate alternative livelihood and that their stated program design is not being implemented in communities. 
The $\mathrm{WoC}$ program provides employment and salaries for approximately 690 Indigenous people (Ryan 2012). This structure provides each individual with adequate remuneration (S. Kerins, pers. comm. 18 March 2015). Rather than compensating for lost hunting opportunities, which are economically and culturally important for Indigenous Australians (Baker et al. 2001), a permit system allows regulated hunting on Indigenous-managed lands in accordance with traditional practices and sustainability principles (Ryan 2012).

Restrictions on harvesting forest products are consistently identified as problematic aspects of conservation programs (Boissière et al. 2009; McElwee 2009). Indeed, Vandergeest and Wittayapak (2010: 6) state that, at a global level, 'the tendency is ... to shift responsibility for resource protection to local communities without granting the rights to use those resources for their livelihoods.' As PES schemes often involve those who rely on the natural environment for their economic and cultural wellbeing, poor economic structuring of programs can be detrimental to the socioeconomic wellbeing of communities. The results suggest that PES programs are better able to deliver socioeconomic benefits to communities when they recognise through their economic structure (a) the ability of communities to harvest forest products sustainably in line with cultural and economic needs and/ or (b) the necessity of payments to compensate adequately for the opportunity costs of conservation such as lost forest product harvests and alternative land uses.

\section{Communities receiving non-monetary benefits from the protection of the environment}

Environmental protection payment schemes are based on providing direct monetary incentives for protecting the environment. However, when communities benefit from the land management itself, as opposed to from the payments only, PES programs are more able to contribute to the socioeconomic wellbeing of communities. As such, the payments allow and incentivise communities to manage land that improves their livelihoods in other ways.

This is illustrated particularly well by the WoC program. Although the wellbeing benefits of Indigenous land management are difficult to measure objectively (Smyth 2012), both independent (Smyth 2012) and government (Ryan 2012) evaluations report substantial, community-wide, non-monetary benefits of the $\mathrm{WoC}$ program. These reports are supported by accounts of the benefits of programs from participants (Green \& Morrison 2012; Marika et al. 2012; Warddeken Land Management Limited 2012). Some of the identified benefits are listed in Table 2. These benefits result from the program's whole-of-community approach and the impact of connectedness with Country and the health of Country on Indigenous people's physical, emotional, cultural and spiritual wellbeing (May, 2010; Green \& 
Morrison 2012; Marika et al.2012). These benefits are also felt particularly strongly in the context of recent colonisation, dispossession and suppression (Green \& Morrison 2012; Marika et al. 2012).

Vietnam's sociocultural context is substantially different to Australia's, meaning that the nature of non-monetary benefits that environmental management can provide is different, although the rationale remains the same. For example, in the study village, a secondary benefit of the PES scheme was the protection of water quality. Water quality is important for agricultural production and domestic use. Maintaining water quality was a key incentive for a successful community forest patrol program in a rural Kinh village visited during the field school. In Vietnam, PES programs might also offer opportunities for capacity building, accessing new technologies or improving infrastructure that would assist with forest management. Protecting the forest might increase the potential for tourism. This could be particularly beneficial in the study village because of the existing tourist venture. In addition, given the Co Tu people's spiritual connections to forests, being able to engage with forests in a way that is compatible with their cultural traditions, such as being legally allowed to hunt, could be an incentive for sustainable management (Bayrak et al. 2013). Bayrak et al. (2013) emphasise that money and the utilitarian values of forests are not the only reasons why Co Tu people would be interested in protecting forests. Engaging with existing community interests allows PES programs to have wellbeing consequences beyond direct monetary remuneration.

\section{Table 2: How land management associated with the Working} on Country program provides benefits to communities.

Working on Country and the associated land management

- Employs community members in purposeful and socially respected jobs that do not rely on welfare or mining royalties

- Supports local economies via salaries

- Allows local infrastructure to be improved

- Allows tourism to be managed in accordance with traditional owners' wishes

- Ensures the concerns and wishes of traditional owners are respected, reducing conflict

- Ensures sacred sites are protected and restored

- Connects and supports homeland communities

- Increases the capacity of communities to obtain funding for future projects

- Promotes the continuation of cultural activities, ceremonies and Indigenous language learning

- Engages youth, with positive outcomes for behaviour, education and cultural maintenance

- Promotes physical activity

- Allows community members to reconnect with their Country. This, in turn, has positive benefits on the physical, mental and spiritual health of community members.

Sources: Green \& Morrison 2012; Marika et al. 2012; Ryan 2012; Warddeken Land Management Limited 2012. 


\section{Communities receiving adequate and appropriate support from outside organisations and the state}

In the study village, the WWF and the provincial government were involved in the PES program. The WWF's conservation goals appeared to be overshadowing their socioeconomic goals. Furthermore, the WWF did not appear to be engaging with the village in a way that allowed conflicts to be resolved. This is despite the WWF's stated aims and acknowledgement of the importance of engaging communities with their programs (Mansourian \& Vallauri 2014). This suggests that the scale of their projects is such that they become removed from the on-the-ground reality of their projects and their outcomes. The precise role of the government in the PES scheme in the study village was unclear. However, other studies have found that the role of the state in environmental management is often more limiting than empowering (KimDung et al. 2013; To et al. 2012). This suggests that outside organisations can impinge on the ability of PES programs to deliver socioeconomic benefits to communities, even if they are the driving force behind the programs.

On the other hand, outside organisations and state support have been essential for the success of WoC. Outside organisations have founded successful partnerships with communities under action research frameworks. For example, as part of the People on Country, Healthy Landscapes and Indigenous Economic Futures research program, researchers balanced the imperative for community action with the importance of meeting research goals and were able to improve the outcomes of Indigenous land management initiatives (Smyth 2012). Non-Indigenous intermediaries have provided crucial institutional and procedural knowledge while acting as representatives for community interests (S. Kerins, pers. comm. 18 March 2015). A focus on capacity building and the community-instigated nature of the programs has eased concerns that programs will collapse when outside organisers leave. The Australian Government's policy design and economic support has allowed the $\mathrm{WoC}$ program to take a whole-of-community approach and incorporate improvements in infrastructure and technology. This has increased the socioeconomic benefits of WoC (May 2010).

This comparison indicates the importance of both adequate and appropriate involvement of outside organisations. Indeed, Pham et al. (2010: 64) argue that 'intermediary boundary organizations'such as NGOs, the state or community groups in Vietnamese PES programs can be crucial, acting 'as service and information providers, mediators, arbitrators, equalizers, representatives, watchdogs, developers of standards and bridge builders'. However, the study village was typical of wider findings that outside organisations can undermine program success when they focus on measurable outputs rather than holistic sustainability, undermine local people's interests, customs and cultures and leave communities without impetus for environmental preservation (Colfer 2005; Mustalahti 2009; Pham et al. 2010; Bayrak et al. 2013; Measham \& Lumbasi 2013). Thus, assuming that communities 
benefit from PES programs at all, wellbeing benefits can be gained from PES when outside organisations, including the state, provide targeted support and empower communities for the long-term rather than merely impose their will on communities in the short-term.

\section{The market, PES theory and program design}

The two examples of PES discussed in this report are not strictly market-based. That is, there are not multiple buyers and sellers of environmental services operating according to processes of supply and demand. Wunder (2013) suggests this is common among current PES schemes. McElwee (2012) and To et al. (2012) both found that because of state intervention, other PES schemes in Vietnam are not underpinned by market mechanisms either, although they have come closer than the two examples examined in this report. The two examples in this report could be considered more community-based and employment-based, in that communities or individuals are paid to actively engage in protecting and managing land, rather than for merely owning and maintaining land that provides environmental services.

There is reason to be sceptical about the claim that monetising the value of the environment in a neoliberal market context can benefit either the environment or communities. There are examples of PES programs that, because of poor property rights regimes and program design which excluded poor people, increased inequality and land degradation (To 2010; To et al. 2012; Dressler et al. 2013). This report suggests that non-market program designs may be valuable for integrating environmental and socioeconomic goals into environmental programs. Engaging communities, as opposed to creating a market, has been effective in Australia, and not detrimental in Vietnam. It is beyond the scope of this report to discuss how a fully fledged competitive market for PES may allow PES programs to incorporate fully the value of the service, the costs of supplying the service and scarcity of service supply, or how this could allow the schemes to benefit communities socioeconomically (see Appendix 1).

\section{Areas for further investigation}

This study has highlighted a difficulty in reconciling the scale at which PES schemes are practically implemented-locally-and the scale at which they are monitored, evaluated and reported on-regionally, nationally and globally. The disparity of scale makes deciding at what level research should be conducted and at what scale that research can inform further actions or policy difficult. There are many reports that evaluate the reasons for success or failure of individual PES case studies. A meta-analysis of these findings, similar to that conducted by Colfer (2005), may provide insights into how best to design PES schemes to achieve 
socioeconomic outcomes more widely. However, this reductionist approach may not be appropriate given the complexity and diversity of the systems involved, and consistent, local reviews may prove more practically useful (Colfer 2005).

Further studies that review the outcomes of the CarBi Project in other villages and the study village in more detail would reveal the representativeness of the results. How local conditions and PES program design affect the efficacy of the programs could then be investigated. For example, power relationships between the state and the village, the WWF and the village or the village chief and the other villagers may be affecting the program outcomes (Pham et al. 2010), but are not discussed in this report. In addition, altering the design of the program and the nature of the environmental services market might provide an avenue for improving the outcomes. Furthermore, given the deep cultural connection between Co Tu people and forests (Bayrak et al. 2013), the cultural impacts of monetising environmental services could be investigated.

\section{Conclusion}

This report has used data collected during a field school in Vietnam as a springboard into an investigation of PES, focusing on possibilities for integrating environmental and socioeconomic sustainability. A Vietnamese village's experiences of PES were compared to the WoC program to illustrate how the shortcomings of PES identified in the study village might be overcome.

This analysis highlighted four factors that influence whether PES programs can contribute to the socioeconomic wellbeing of communities. Community involvement in the design, implementation and review of programs improves the likelihood that program design takes into account the needs of the community and will not undermine socioeconomic wellbeing. An economic framework that takes into account the opportunity costs of conservation ensures that environmental preservation will also not undermine the livelihoods of those involved. Nonmonetary benefits associated with the land management itself provide incentives for participation in programs and spreads benefits to entire communities. Finally, outside organisations that work to support, rather than control, communities allow communities to benefit from PES schemes without undermining their sociocultural integrity. These community-level conditions are important regardless of the specific design of PES programs and the nature of the market, as indicated by the applicability of all these factors to the contrasting contexts of Vietnam and Australia. Yet, the factors covered in this report are the ones that emerged from the study village, and are not necessarily the causal, sole, or critical factors for the success of every PES program. 
PES programs can be highly problematic, but WoC illustrates that they do have the potential to integrate economic, social and environmental sustainability. Programs must be carefully implemented and reviewed at a local level as they operate in highly complex systems. Only when this complexity is acknowledged and addressed through community involvement and program design will PES contribute to communities' socioeconomic wellbeing.

\section{Appendix 1: Evolution of research}

The research for this report was emergent. That is, it resulted from observations during a field school rather than a pre-defined question and method. Observing several communities in Vietnam benefiting from managing forests, as alluded to in the non-monetary benefits section, inspired further research. An existing interest in Australian Indigenous cultural and natural resource management and its relationship to community-level sociocultural-economic wellbeing meant that I was looking for similar connections while in Vietnam. This approach allowed my initial observations to be broad-based and unrestricted by attempting to answer a specific question.

This project began as an investigation into community-based environmental management. It transitioned into a PES-focused project when I learned that the study village was receiving PES. As a result, this report is community-focused, as opposed to focused on market mechanisms, property rights, transaction costs and other factors that are important for successful PES schemes and may otherwise have been investigated (Engel et al. 2008). The sign in Figure 2 helped identify which WWF program the study village was involved in and instigated an investigation into the role of outside organisations in PES programs. The literature review indicated that the village was experiencing some 'typical' difficulties associated with PES and that the success of $\mathrm{WoC}$ was quite rare and based on the applicability of the program to the Indigenous Australian context. Hence, this report emphasises the importance of local conditions.

\section{Bibliography}

Adhikari, B. and Agrawal, A., 2013. Understanding the social and ecological outcomes of PES projects: A review and an analysis, Conservation and Society, 11: $359-374$.

Altman, J.C., 2012. People on Country as Alternate Development, in People on Country: Vital Landscapes, Indigenous Futures, eds J. Altman and S. Kerins, The Federation Press, Sydney, pp. 1-22. 
Asia News Monitor, 2009. Vietnam: New forests help ease poverty, Asia Nerws Monitor 12 March.

Baker, R., Davies, J. and Young, E., 2001. Working on Country: Contemporary Indigenous Management of Australia's Lands and Coastal Regions, Oxford University Press, South Melbourne.

Barbier, E.B., 2010. Poverty, development, and environment, Environment and Development Economics, 15: 635-660.

Bayrak, M.M., Tu, T.N. and Burgers, P., 2013. Restructuring space in the name of development: The socio-cultural impact of the Forest Land Allocation Program on the indigenous Co Tu people in Central Vietnam, Journal of Political Ecology, 20: $37-52$.

Bekker, F., 2015. Six Monthly Technical Progress Report July 2014-December 2014 for the BMU/ICI project Avoidance of deforestation and forest degradation in the border area of Southern Laos and central Vietnam for the long-term preservation of carbon sinks and biodiversity ('CarBi Project'), World Wildlife Fund, d2ouvy59p0dg6k. cloudfront.net/downloads/6_monthly_carbi_website_tpr_jul__dec_2014. pdf, accessed 28 March 2015.

Boissière, M., Sheil, D., Basuki, I., Wan, M. and Le, H., 2009. Can engaging local people's interests reduce forest degradation in Central Vietnam?, Biodiversity Conservation, 18: 2743-2757.

Colfer, C.J.P., 2005. The Complex Forest: Communities, Uncertainty, \& Adaptive Collaborative Management, Resources for the Future, Washington, DC.

Dressler, W.H., To, P.X. and Mahanty, S., 2013. How biodiversity conservation policy accelerates agrarian differentiation: The account of an upland village in Vietnam, Conservation and Society, 11: 130-143.

Engel, S., Pagiola, S. and Wunder, S., 2008. Designing payments for environmental services in theory and practice: An overview of the issues, Ecological Economics, 65: 663-674.

Green, J. and Morrison, J., 2012. No more yardin' us up like cattle, in People on Country: Vital Landscapes, Indigenous Futures, eds J. Altman and S. Kerins, The Federation Press, Sydney, pp. 190-201.

Hidayat, H., Kono, Y. and Le, X.P., 2012. From plantation forestry to the pulp and paper industry: A case study of Vietnam, South Pacific Studies, 33: 53-76.

KimDung, N., Bush, S. and Mol, A.P.J., 2013. Administrative co-management: The case of special conservation in Vietnam, Environmental Management, 51: 616-630. 
Mansourian, S. and Vallauri, D., 2014. Restoring forest landscapes: Important lessons learnt, Environmental Management, 53: 241-251.

Marika, B., Munyarryun, B., Munyarryun, B., Marawili, M. and Marika, W., 2012. Ranger djama? Manymak!, People on Country: Vital Landscapes, Indigenous Futures, in eds J. Altman and S. Kerins, The Federation Press, Sydney, pp. $132 \circ 145$.

May, K., 2010. Government support for Indigenous cultural and natural resource management in Australia: The role of the Working on Country program, The Australian Journal of Social Issues, 45: 395-416.

McElwee, P.D., 2009. Reforesting 'bare hills' in Vietnam: social and environmental consequences of the 5 million hectare reforestation program, AMBIO, 38: 325-333.

McElwee, P.D., 2012. Payments for environmental services as neoliberal market based forest conservation in Vietnam: panacea or problem?, Geoforum, 43: 412-426.

Measham, T.G. and Lumbasi, J.A., 2013. Success Factors for Community-Based Natural Resource Management (CBNRM): Lessons from Kenya and Australia, Environmental Management, 52: 649-659.

Menon, A., Singh, P., Esha, S., Lele, S., Paranjape, S. and Joy, K.J.,2007. Communitybased Natural Resource Management: Issues and Cases from South Asia, SAGE Publications [Online].

Millennium Ecosystem Assessment, 2005. Ecosystems and Human Well-being: Synthesis, Island Press, Washington, DC, www.millenniumassessment.org/en/ Reports.html, accessed 14 March 2015.

Mustalahti, I., 2009. Sustaining Participatory Forest Management: Case Study Analyses of Forestry Assistance from Tanzania, Mozambique, Laos and Vietnam, Small-scale Forestry, 8: 109-129.

Pagiola, S., Arcenas, A. and Platais, G., 2005. Can payments for environmental services help reduce poverty? An exploration of the issues and evidence to date from Latin America, World Development, 33: 237-253.

Pham, T.T., Campbell, B.M., Garnett, S., Aslin, H. and Hoang, M.H., 2010. Importance and impacts of intermediary boundary organizations in facilitating payment for environmental services in Vietnam, Environmental Conservation, 37: 64-72. 
Ryan, R., 2012. Assessment of the Social Outcomes of the Working on Country Program, Department of Sustainability, Environment, Water, Population and Communities, apo.org.au/node/30840, accessed 27 February 2015.

Sam, D.D. and Trung, L.Q., 2001. Forest policy trends in Vietnam, in Policy Trend Report 2001, The Institute for Global Environmental Strategies, Kanagawa, pp. 69-73.

Sheil, D., Puri, R., Wan, M., Basuki, I., van Heist, M., Liswanti, N., Rukmiyati, Rachmatika, I. and Samsoedin, I., 2006. Recognizing local people's priorities for tropical forest biodiversity, $A M B I O, 35: 17-24$.

Smyth, D., 2012. Final evaluation report: People on country end project evaluation, in People on Country, Healthy Landscapes and Indigenous Economic Futures 2012 Annual Report, ed. A. Thomassin, 2013. Centre for Aboriginal Economic and Policy Research, Canberra, pp. 43-79.

Sodhi, N. S., Koh, L. P., Clements, R., Wanger, T. C., Hill, J. K., Hamer, K. C., Clough, Y., Tscharntke, T., Posa, M. R. C. and Lee, T. M., 2010. Conserving Southeast Asian forest biodiversity in human-modified landscapes, Biological Conservation, 143: 2375-2384.

The, B.D. and Ngoc, H.B., 2008. Payments for environmental services in Vietnam: An empirical experiment in sustainable forest management, ASEAN Economic Bulletin, 25: 48-59.

Thuy, T.T., Bennet, K., Vu, T.P., Brunner, J., Le, N.D. and Nguyen, D.T., 2013. Payments for Forest Environmental Services in Vietnam: From Policy to Practice, Centre for International Forestry Research, Bogor, Indonesia.

To, P.X., 2010. Elite capture and local inequality, in The Politics of Decentralisation: Natural Resource Management in Asia, eds C. Wittayapak and P. Vandergeest, Mekong Press, Chiang Mai, pp. 57-74.

To, P.X., Dressler, W.H., Mahanty, S., Pham, T.T. and Zingerli, C., 2012. The prospects for payment for ecosystem services (PES) in Vietnam: A look at three payment schemes, Human Ecology Interdisciplinary Journal, 40: 237-249.

Tole, L., 2010. Reforms from the ground up: a review of community-based forest management in tropical developing countries, Environmental Management, 45: 1312-1331.

Tsing, A.L., Brosius, J.P. and Zerner, C., 2005. Introduction: Raising questions about communities and conservation, in Communities and Conservation: Histories and Politics of Community-Based Natural Resource Management, eds J.P. Brosius, A.L. Tsing and C. Zerner, Altamira Press, Walnut Creek, pp. 1-34. 
Vandergeest, P. and Wittayapak, C., 2010. Decentralization and politics, in The Politics of Decentralization: Natural Resource Management in Asia, eds C. Wittayapak and P. Vandergeest, Mekong Press, Chiang Mai, pp. 1-20.

Vu, Q.M., Le, Q.B., Frossard, E. and Vlek, P.L.G., 2014. Socio-economic and biophysical determinants of land degradation in Vietnam: An integrated causal analysis at the national level, Land Use Policy, 36: 605-617.

Warddeken Land Management Limited, 2012. Warddeken Land Management Limited: Annual Report 2011-2012, Warddeken Land Management Limited, Nightcliff.

Wunder, S., 2013. When payments for environmental services will work for conservation, Conservation Letters, 6: 230-237.

WWF (World Wildlife Fund), 2015. CarBi Project, World Wildlife Fund, wwf. panda.org/what_we_do/where_we_work/greatermekong/our_solutions/ projects/carbi/, accessed 28 March 2015.

\section{Acknowledgements}

The author thanks Trung Dang Dinh for translating during the field school and Dr David Freudenberger for convening the field school and supervising this research project. Thanks are also due to Sean Kerins from the Centre for Aboriginal Economic and Policy Research at The Australian National University for providing insights into and resources about the Australian Indigenous PES context. 
This text is taken from The ANU Undergraduate Research Journal, Volume Seven, 2015, edited by Daniel McKay, published 2016 by ANU eView, The Australian National University, Canberra, Australia. 